\title{
Nitric Oxide-Induced Cytotoxicity: Involvement of Cellular Resistance to Oxidative Stress and the Role of Glutathione in Protection
}

\author{
M. WHIT WALKER, MICHAEL T. KINTER, ROBERT J. ROBERTS, AND DOUGLAS R. SPITZ \\ University of Virginia Health Sciences Center, Division of Neonatology, Departments of Pediatrics and \\ Pathology, University of Virginia Hospital, Charlottesville, Virginia 22908 [M.W.W., M.T.K., R.J.R.], and \\ Mallinckrodt Institute of Radiology, Radiation Oncology Center, Section of Cancer Biology, \\ Washington University Medical Center, St. Louis, Missouri 63108 [D.R.S.]
} \begin{abstract}
ABS
A series of experiments were designed to examine the poten-
tial cytotoxicity of nitric oxide (NO), or reactive species derived from $\mathrm{NO}$, in $\mathrm{HA} 1$ fibroblasts and $\mathrm{H}_{2} \mathrm{O}_{2}$-resistant variants of this cell line, designated $\mathrm{OC} 14$ cells. A 1 -h exposure at $37^{\circ} \mathrm{C}$ to a 1.7 $\mathrm{mM}$ bolus dose of $\mathrm{NO}$, prepared in $\mathrm{N}_{2}$-gassed medium, significantly reduced clonogenic survival in the HA1 fibroblasts line to $60 \%$ of control cells treated with $\mathrm{N}_{2}$-gassed medium alone. The OC14 cells were found to be completely resistant $(100 \%$ survival) to NO-mediated injury in comparable experiments. A second set of experiments was designed to determine the role of the intracellular antioxidant, glutathione, in protection against NO-mediated injury. Depletion of total glutathione resulted in a significant reduction in HA1 and OC14 clonogenic survival to $8 \%$ and $50 \%$ when compared with respective control cells. The effect of total glutathione depletion on NO-initiated toxicity in HA1 cells was dose- and cell-density dependent and was observed to occur within $5 \mathrm{~min}$ of exposure to NO. Further evidence of cytotoxicity was demonstrated by loss of trypan blue dye exclusion properties in glutathione-depleted HA1 cells after
\end{abstract}

NO exposure. Other experiments demonstrated that nitrate and nitrite exposure produced no cytotoxicity in glutathione-depleted HA1 cells and that coincubation of NO-saturated medium with oxyhemoglobin inhibited NO-induced cytotoxicity in glutathione-depleted HA1 cells. These results demonstrate that $l$ ) nitric oxide, or an NO-derived reactive nitrogen species other than nitrites or nitrates, is responsible for reduction in clonogenic survival and trypan blue dye exclusion capabilities in vitro; 2) biochemical pathways associated with cellular resistance to oxidative stress also confer resistance to NO-mediated injury in this cell model; and 3) total glutathione content determines a significant portion of cell sensitivity to NO-mediated cytotoxicity. (Pediatr Res 37: 41-49, 1995)
Abbreviations
BSO, L-buthionine-S, R-sulfoximine
NO, nitric oxide
$\mathrm{NO}_{2}$, nitrogen dioxide
MEM, minimal essential medium

NO is a free radical molecule endogenously produced by a variety of cell types. NO has been demonstrated to participate in physiologic reactions involving regulation of vasomotor tone, neurotransmission, immune system function, and platelet aggregation (1-4). Recent clinical trials have demonstrated some efficacy for inhaled NO in treatment of neonatal pulmonary hypertension and adult respiratory distress syndrome (57). Paradoxically, elevated concentrations of atmospheric NO are known to be harmful in many animal models, and lethal exposures at high concentrations have been reported in both animals and humans $(8-10)$. This same paradoxical beneficial and/or toxic effect of NO has been observed in vitro. Several

Received August 10, 1993; accepted July 8, 1994.

Correspondence: Dr. M. Whit Walker, Department of Neonatology, Greenville Hospital Systems, 701 Grove Road, Greenville, SC 29605.

Supported by National Institutes of Health Grants HL42057, HL08841, HL51469, CA51116, HD28810, GM08260, and DK38924 investigators have reported that endogenously derived NO, or NO released from pharmacologic agents, can function in cytoprotective responses to injury initiated by ischemiareperfusion or other pathologic conditions (11-14). Conversely, other investigators report that endogenously generated or exogenously administered NO may initiate or contribute to cytotoxic reactions seen in neural, cardiac, and endothelial tissue after similar experiments designed to evaluate the interactions of NO and ischemia-reperfusion (15-18). Clearly, NO can have beneficial, as well as cytotoxic, properties depending on the system and initial conditions that are being studied.

Recently, Wink et al. (19) demonstrated that aqueous phase NO in the presence of oxygen reacted to form a reactive nitrogen oxide that is both a potent oxidant and a nitrosating agent. This reactive nitrogen oxide, NOx, was determined not to be one of the commonly proposed reactive nitrogen species, such as peroxynitrite $\left(\mathrm{OONO}^{-}\right), \mathrm{NO}_{2} \cdot \mathrm{N}_{2} \mathrm{O}_{3}$, or $\mathrm{NO}^{+}$(19). 
Because this NOx species derived from NO is a potent oxidant, we hypothesized that biochemical pathways associated with resistance to oxidative stress might also confer resistance to NO-mediated toxicity associated with exposure to NO in the aqueous phase.

The goal of our study was to characterize the toxic potential of bolus exposure to aqueous NO in a cell culture system and to investigate mechanisms of resistance to oxidative stress as potential modifiers of NO-mediated cytotoxicity. Specifically, we chose to examine the clonogenic survival response and trypan blue dye exclusion capabilities of HA1 Chinese hamster fibroblasts after exposure to NO in comparison with similar experiments with OC14 fibroblasts, which have been selected for resistance to hydrogen peroxide-mediated oxidative stress (20). We also depleted the intracellular total glutathione content of both cell types with BSO to test the hypothesis that intracellular stores of free, nonprotein, reduced thiols, known to actively bind $\mathrm{NO}$, would contribute to resistance from NO-mediated cytotoxicity.

\section{METHODS}

Cells and culture conditions. Chinese hamster fibroblasts (HA1) and $\mathrm{H}_{2} \mathrm{O}_{2}$-resistant variants derived from HA1 cells (designated OC14 cells) were cultured as described (20). Briefly, cells were passaged in Eagle's MEM with 10\% FCS and grown to confluence $\left(8 \times 10^{6}\right)$ in T-75 $\mathrm{cm}^{2}$ flasks over 48 h. Cells were trypsinized $(0.1 \%$ trypsin, $0.53 \mathrm{mM}$ EDTA, in Puck's saline) and plated in $60-\mathrm{mm}$ dishes such that at the beginning of each experiment ( $36-48 \mathrm{~h}$ postplating), each dish contained $1-2 \times 10^{6}$ cells. Cultures were maintained in a room air, $5 \% \mathrm{CO}_{2}$, humidified, $37^{\circ} \mathrm{C}$ incubator (NUAIRE, Plymouth, $\mathrm{MN}$ ) for the duration of the experiment. Treatment medium was Eagle's MEM without FCS or phenol red (to prevent inadvertent binding of NO). BSO (Sigma Chemical Co., St. Louis, MO), was added to selected dishes in a $250 \mu \mathrm{M}$ concentration and allowed to incubate for $16 \mathrm{~h}$ before exposure to treatment medium to deplete total intracellular glutathione. After BSO pretreatment, total cellular glutathione was below the limits of assay detection $(0.2 \mu \mathrm{g} / \mathrm{mg}$ protein). Concentrations of NO, oxyhemoglobin, and nitrites or nitrates used are specified in the figures. All treatments were for a duration of 1 $\mathrm{h}$ at $37^{\circ} \mathrm{C}$ unless otherwise indicated.

Clonogenic survival and trypan blue exclusion. Clonogenic survival was determined in trypsinized cultures by a method used routinely in our laboratory $(20,21)$. Normal sham-treated plating efficiencies for HA1 and OC14 cells range from 60 to $90 \%$ and were determined in each experiment. Sham-treatment consisted of exposure to medium prepared by nitrogen gassing. Survival data from reactive nitrogen species-treated cells were compared with sham-treated or BSO-treated control plating efficiencies and plotted as a function of time or dose. Trypan blue dye exclusion was done in situ by washing the treated cells with saline and adding $0.04 \%$ trypan blue dye in isotonic saline. After a 5-min incubation, the dye was washed off the dish with saline and the number of cells excluding dye was expressed as a percentage of 100 cells counted from two randomly chosen areas of the dish. All experiments were accomplished in duplicate, unless otherwise stated. Within each experiment, treatment groups were tested in triplicate and each treatment culture dish was subsequently plated for clonogenic survival in triplicate.

Preparation of $\mathrm{NO}$ solutions. $\mathrm{N}_{2}$-gassed medium was prepared at $25^{\circ} \mathrm{C}$ by bubbling FCS-free, phenol red-free Eagle's MEM (GIBCO, Grand Island, NY) for $15 \mathrm{~min}$ with $\mathrm{N}_{2}$ in gas-tight containers fitted with gas-tight stoppers and a bleeder valve. For experiments, NO-containing medium was prepared by bubbling approximately $100 \mathrm{~mL}$ of $99.99 \%$ NO gas (Matheson Gas Co., Cucumonga, CA) into $100 \mathrm{~mL}$ of $\mathrm{N}_{2}$-gassed medium for $3 \mathrm{~min}$. Because NO bubbling in excess of $4-7 \mathrm{~mL}$ gas/100 mL medium resulted in "supersaturated"' solutions of $\mathrm{NO}, \mathrm{pH}$ of the medium was monitored and adjusted with $\mathrm{NaOH}$ or $\mathrm{HCl}$ to maintain a range of 7.2 to 7.8. Dilutions of saturated NO medium were made by mixing appropriate concentrations of the $\mathrm{N}_{2}$-gassed control medium with NOcontaining medium in gas-tight syringes. $\mathrm{NO}$, dissolved in medium, was assayed using a chemiluminescence detection method based on the reaction of NO with ozone. Quantitative measurements of NO in medium were made with a Sievers Research Redox Chemiluminescence Detector, model NOA 270 (Sievers Research, Boulder, CO). The lower limit of detection by this method is 22 pmol $(22,23)$.

Nitrite determination and oxyhemoglobin preparation. $\mathrm{Ni}$ trite $\left(\mathrm{NO}_{2}{ }^{-}\right)$content was determined spectrophotometrically using a procedure based on the Griess reaction (24). Sample aliquots were mixed with the Griess reagent that contained 1 part $0.1 \%$ naphthylethylenediamine dihydrochloride in distilled $\mathrm{H}_{2} \mathrm{O}$ plus 1 part $1 \%$ sulfanilamide in $5 \%$ concentrated $\mathrm{H}_{3} \mathrm{PO}_{4}$, and absorbance was determined at $546 \mathrm{~nm}$. For quantification of nitrite in the medium, culture medium was deproteinized with $35 \%$ sulfosalicyclic acid and centrifuged at $10000 \times g$ for $15 \mathrm{~min}$, and the supernatant was combined with $5 \%$ aqueous $\mathrm{NH}_{4} \mathrm{Cl}$ buffer and $5 \% \mathrm{NaOH}$ before analysis. Oxyhemoglobin was prepared by reducing bovine crystalline $\mathrm{Hb}$ (Sigma Chemical Co.) with $10 \mathrm{M}$ equivalents of sodium dithionite. Excess reducing agent was removed from the $\mathrm{Hb}$ solution by passage over a Sephadex G25 column and spectrophotometric analysis confirmed the presence of bovine deoxyhemoglobin by the absorbance at $431 \mathrm{~nm}$ (25). Oxyhemoglobin was formed upon exposure of deoxyhemoglobin to $21 \%$ oxygen and confirmed spectrophotometrically by the absorbance peak at $414 \mathrm{~nm}$. Oxyhemoglobin was added, at $100 \mu \mathrm{M}$ final concentration, to selected treatment cultures immediately before NO addition. Spectrophotometric analysis for the presence of methemoglobin, the final metabolic product of the NO-oxyhemoglobin reaction, was performed after NO treatment by absorbance peak determination at $406 \mathrm{~nm}$.

Glutathione assay. Total glutathione (reduced glutathione + oxidized glutathione) was determined by an oxidized glutathione reductase recycling assay routinely used in our laboratory (26). All data were normalized per mg protein.

Statistical analysis. Analysis of clonogenic survival was performed using analysis of variance for multiple points. Statistical significance at $p<0.05$ was confirmed using Bonferroni's comparison. Analysis of trypan blue dye exclusion and total 
glutathione were performed using the $t$ test with statistical significance at $p<0.05$.

\section{RESULTS}

The cytotoxicity of exogenously administered NO was determined by exposing immortalized Chinese hamster fibroblasts, HA1 cells, to known concentrations of NO for specific periods of time. Injury was quantitated by clonogenic cell survival and trypan blue dye exclusion. As shown in Figure 1, exposure of HA1 fibroblasts to saturated, $1.7 \mathrm{mM}$ NOcontaining medium for $1 \mathrm{~h}$ caused a $40 \%$ reduction in clonogenic cell survival relative to control cells exposed to $\mathrm{N}_{2}$ gassed medium alone. These conditions produced no differences in the percentage of cells capable of excluding trypan blue dye between control and NO-treated HA1 cells (>95\% exclusion). Figure 1 also demonstrates that depletion of total intracellular glutathione, performed before NO exposure, results in a significant reduction in clonogenic cell survival in HA1 cells to $<20 \%$. Glutathione depletion alone had no effect on HA1 clonogenic survival. An additional manifestation of NO-mediated cytotoxicity seen in total glutathionedepleted HA1 cells was the loss of the ability to exclude trypan blue dye ( $>95 \%$ loss) (Fig. 1). Thus, the total glutathionedepleted HA1 cells were significantly more sensitive to NOmediated toxicity than non-glutathione-depleted HA1 cells as determined by both clonogenic survival and trypan blue dye exclusion.

The significant reduction in clonogenic cell survival in NO-treated, total glutathione-depleted HA1 cells was both dose dependent and cell density dependent. Total glutathionedepleted HA1 cells had an almost linear reduction in clono- genic cell survival as NO concentration increased from 250 to $1700 \mu \mathrm{M}$ (Fig. 2A). Increasing the cell density per culture dish of total glutathione-depleted HA1 cells resulted in increased clonogenic cell survival after exposure to saturated, $1.7 \mathrm{mM}$, NO-containing medium (Fig. 2B).

Clonogenic survival of total glutathione-depleted HA1 cells was markedly decreased after NO-treatment as brief as $5 \mathrm{~min}$ (Fig. 3). This rapid reduction in clonogenic cell survival was not significantly enhanced by longer exposures to saturated concentrations $(1.7 \mathrm{mM})$ of NO. However, exposure of total glutathione-depleted HA1 cells to a relatively low dose of NO $(0.17 \mathrm{mM})$ for up to $6 \mathrm{~h}$ did not significantly affect clonogenic survival (data not shown).

Experiments to determine the cytotoxic effects of NO, with and without intracellular total glutathione depletion, were repeated in OC14 cells to further delineate the protective contribution of adaptation to oxidative stress and total glutathione to NO-induced cytotoxicity. OC14 cells are known to contain 2to 3-fold greater concentrations of total glutathione compared with HA1 cells (26). In contrast to HA1 cells, OC14 cells did not exhibit significant reductions in clonogenic cell survival after 1-h exposures to saturated NO solutions (Fig. 4). NO exposure resulted in a significant reduction in clonogenic cell survival in total glutathione-depleted OC14 cells to $50 \%$ of controls. However, OC14 cells were relatively more resistant to NO-induced injury after total glutathione depletion than were the total glutathione-depleted HA1 cells (50 versus $8 \%$ surviving fraction in experiments with equal cell-plating densities) despite total glutathione levels below the limits of assay detection $(0.2 \mu \mathrm{g} / \mathrm{mg}$ protein) in both cell lines. Both HA1 and OC14 cell types exhibited significantly decreased total gluta-

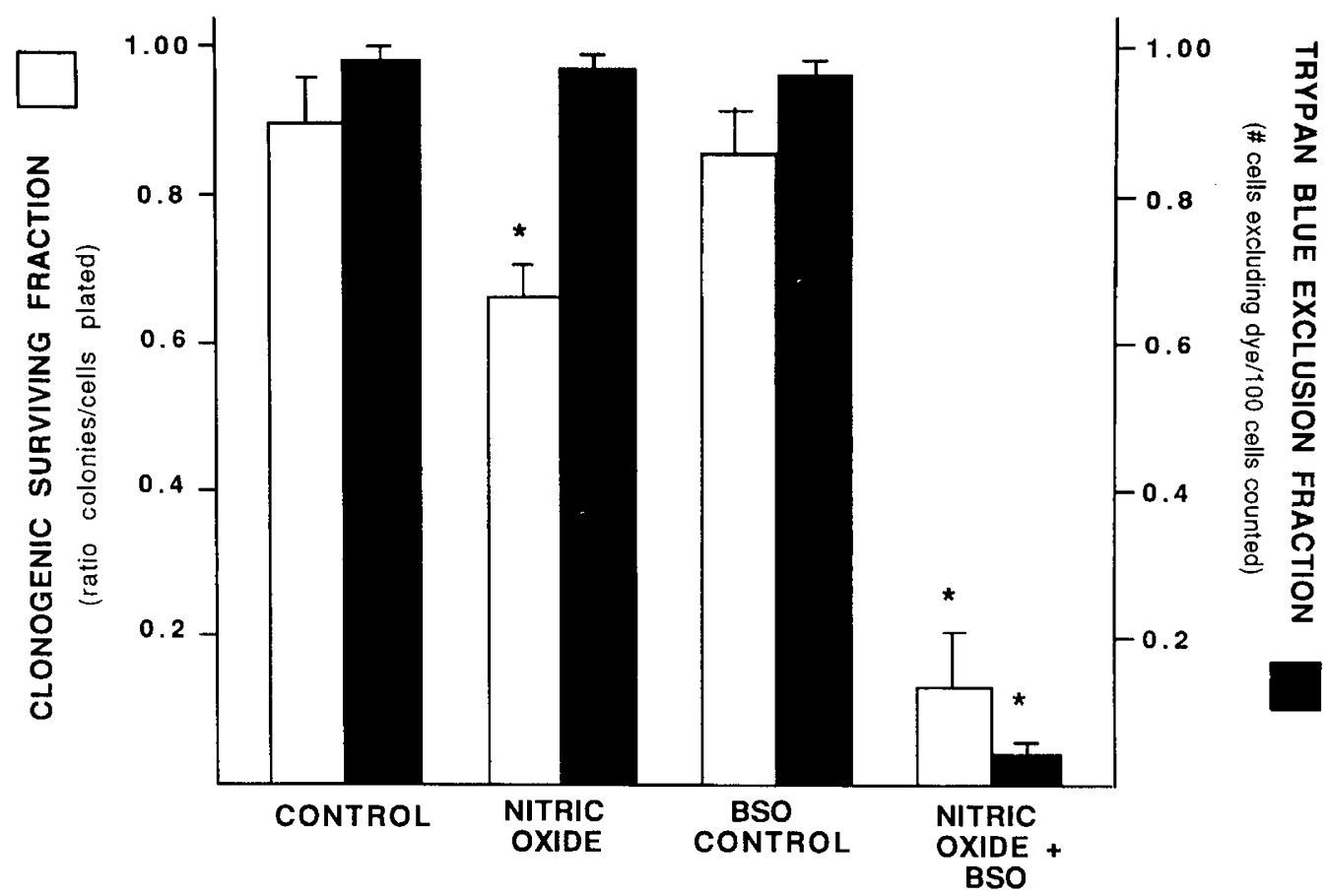

Figure 1. Effects of total glutathione depletion on clonogenic survival and trypan blue exclusion demonstrated by NO-treated HA1 cells. Effects of a 60 -min exposure to saturated $(1.7 \mathrm{mM})$ NO solutions on clonogenic survival and trypan blue dye exclusion of HA1 fibroblasts with and without BSO pretreatment. Total glutathione content in BSO-treated HA1 cells was below the assay limit of detection. Data expressed as mean \pm SD. An asterisk represents $p<0.05 v s$ respective control. 

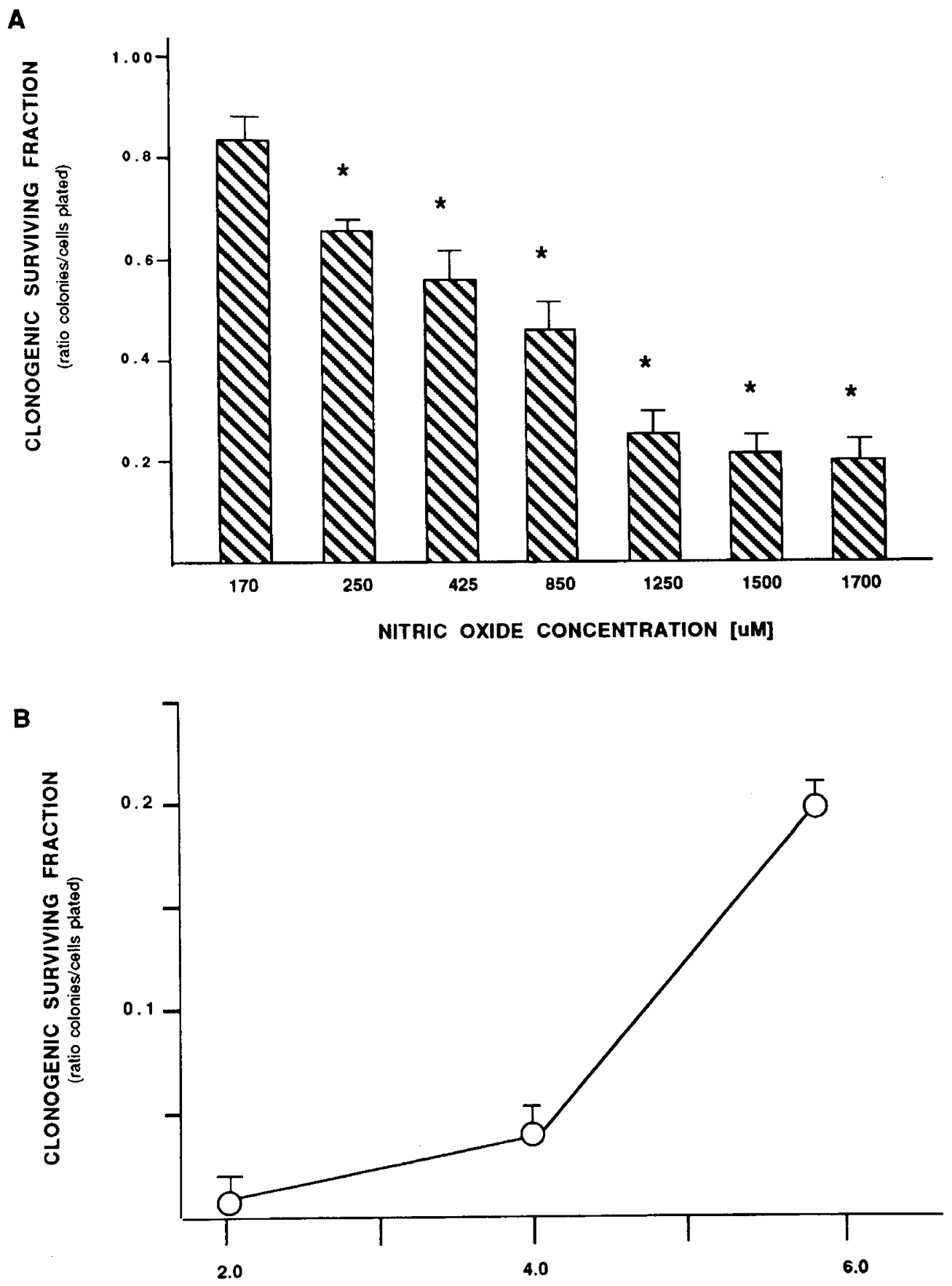

CELL PLATING DENSITY

$$
\text { ( } \times 10^{6} \text { colls/dish) }
$$

Figure 2. A, Effects of increasing concentrations of NO on clonogenic survival of total glutathione-depleted HA1 cells. $B$, Effects of increasing cell density on clonogenic survival of $1.7 \mathrm{mM}$ NO-treated, total glutathione-depleted HA1 cells. Clonogenic survival of BSO-pretreated HA1 fibroblasts after a 60-min exposure to increasing concentrations of NO. Data expressed as mean $\pm \mathrm{SD}$. An asterisk represents $p<0.05 v s$ control.

thione levels after exposure to NO alone (Fig. 5). The disappearance of total glutathione in both cell lines after NO treatment suggests glutathione was being consumed during the treatment interval. This result, in combination with results using total glutathione-depleted HA1 and OC14 cells (Figs. 1 and 4), indicate that reactions involving glutathione play an important cytoprotective role during exposure to NO.
Aqueous NO is rapidly converted to other species after exposure to oxygen (19). Chemiluminescent quantification of saturated NO solutions demonstrated a NO concentration of $1.7 \mathrm{mM}$ at $25^{\circ} \mathrm{C}$ before exposure to oxygen. No nitrites could be detected in stock $\mathrm{N}_{2}$-gassed phenol red- and serum-free MEM using the Griess reaction. No brown gas (indicative of gas phase $\mathrm{NO}_{2}$. formation after reaction of $\mathrm{NO}+$ oxygen) was 


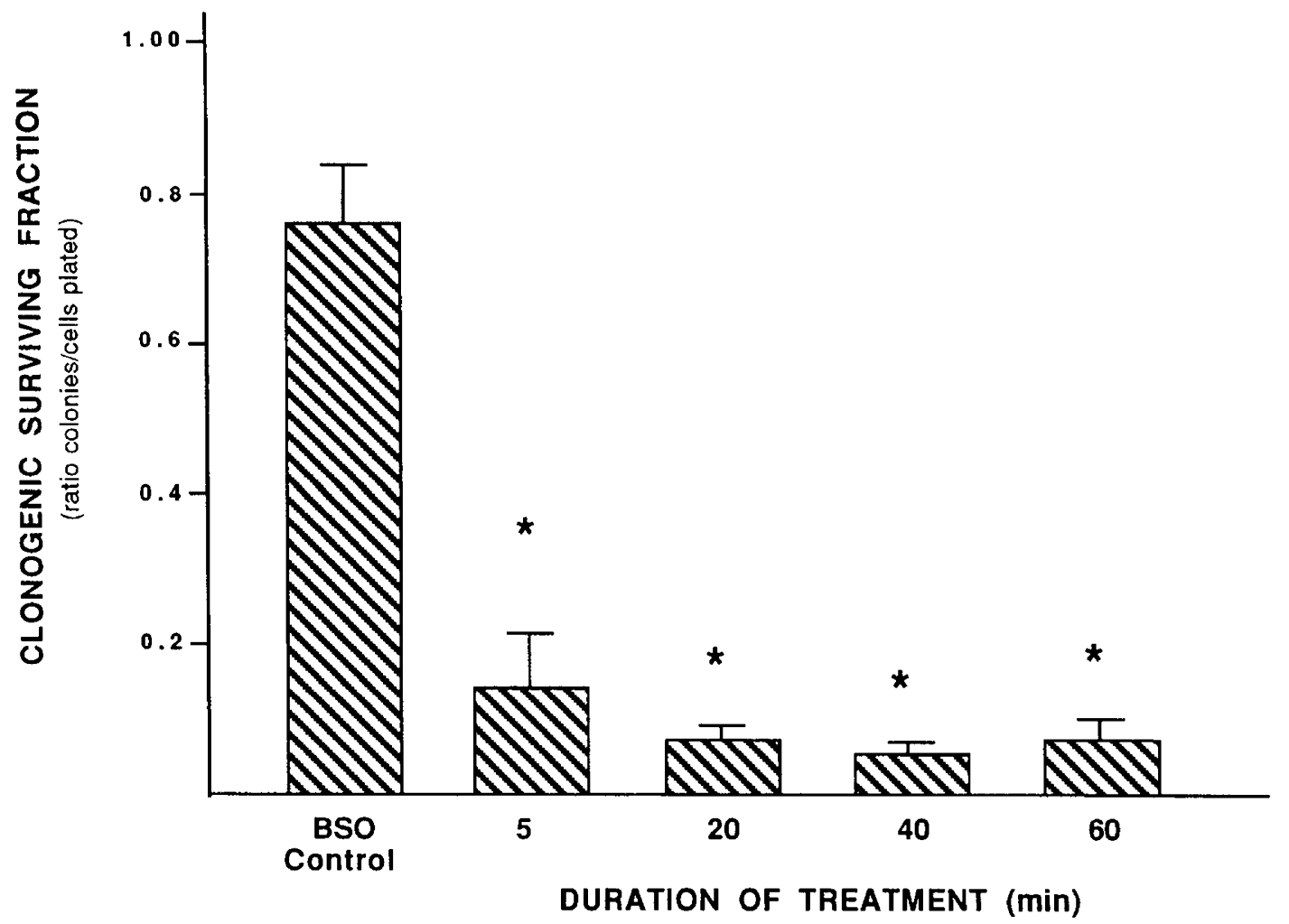

Figure 3. Effects of exposure duration of total glutathione-depleted HA1 cells exposed to saturated NO-containing solutions. Clonogenic survival of BSO pretreated HA1 fibroblasts after increasing durations of exposure (5-60 min) to saturated NO-containing medium. Data expressed as mean \pm SD. An asterisk represents $p<0.05$ vs control.

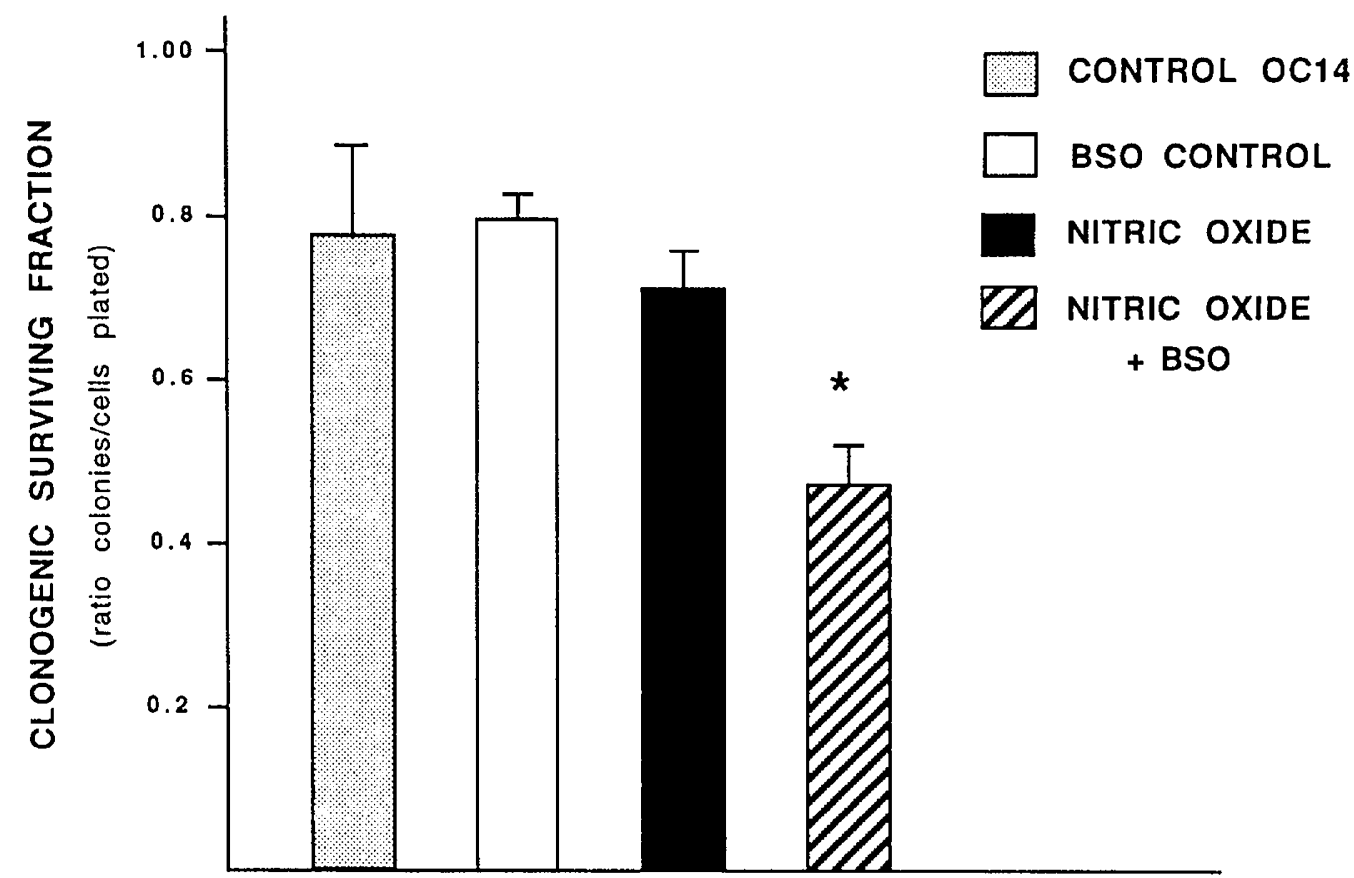

Figure 4. Effects of total glutathione depletion on clonogenic survival of NO-treated OC14 fibroblasts. Clonogenic survival of OC14 fibroblasts with and without BSO pretreatment after a 60 -min exposure to saturated concentrations $(1.7 \mathrm{mM})$ of NO. Total glutathione content in BSO-treated OC14 cells was below the assay limit of detection. Data expressed as mean $\pm \mathrm{SD}$. An asterisk represents $p<0.05$ vs respective control.

present in any medium bottle at any time during the experiment. To evaluate whether nitrites or nitrates could represent the cytotoxic agent responsible for clonogenic inactivation in the previous NO experiments, total glutathione-depleted HA1 cells were incubated with $5 \mathrm{mM}$ nitrite or nitrate. No signifi- cant change in clonogenic survival was seen with either nitrate or nitrite after $1 \mathrm{~h}$ of treatment (Fig. 6).

Finally, experiments were designed to evaluate the protective effects of coincubating NO with oxyhemoglobin, a molecule known to have potent, irreversible binding affinity for $\mathrm{NO}$ 


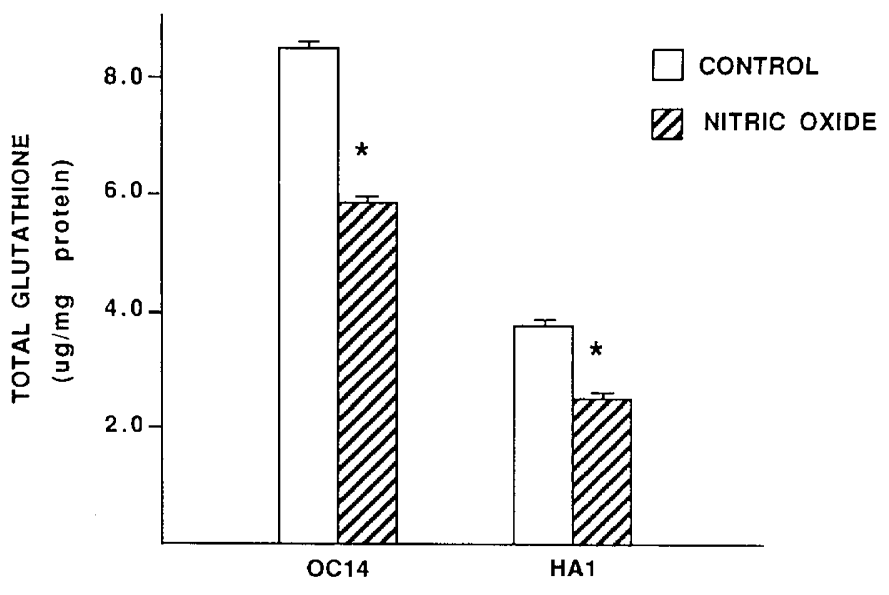

Figure 5. Total cellular glutathione content of HA1 and OC14 fibroblasts after exposure to saturated NO-containing solutions. Total glutathione content of HA1 and OC14 fibroblasts before and after a 60 -min exposure to $1.7 \mathrm{mM}$ NO-containing medium solutions. An asterisk represents $p<0.05$ vs control.

(2). Addition of oxyhemoglobin to NO-saturated medium immediately before cell exposure resulted in a significant increase in clonogenic cell survival when total glutathione-depleted HA1 cells were exposed to saturated solutions of NO (Fig. 7).

\section{DISCUSSION}

Our observations demonstrated that exposure of HA1 fibroblasts to aqueous $\mathrm{NO}$ prepared in $\mathrm{N}_{2}$-gassed medium resulted in a significant reduction in clonogenic cell survival. In addition, the concentration of endogenous intracellular total glutathione in HA1 and OC14 cells is reduced after exposure to exogenous NO. Previous depletion of HA1 intracellular gluta- thione (a major intracellular reserve of nonprotein free thiols capable of interacting with oxidizing agents) $(46,47)$ significantly enhances the NO-mediated cytotoxicity in a dose- and cell density-dependent fashion. Total glutathione depletion, before exposure to NO, resulted in a significant reduction in the ability of HA1 cells to exclude trypan blue dye, another acute indicator of cytotoxicity. NO-mediated cytotoxic effects on clonogenic cell survival in total glutathione-depleted HA1 cells are rapid $(5 \mathrm{~min})$ and dose dependent. These results are consistent with the hypothesis that NO or other reactive nitrogen species derived from the aqueous NO-oxygen reaction mediate the clonogenic inactivation of cells through a pathway that can be inhibited to a significant extent by cellular glutathione.

In another series of experiments, we have shown that the OC14 cell line, which demonstrates a stable $\mathrm{H}_{2} \mathrm{O}_{2}$-resistant phenotype (20), is cross-resistant to the toxicity associated with exposure to aqueous NO. OC14 cells are known to have elevated concentrations of intracellular total glutathione that are two to three times the amount of glutathione found in HA1 cells (26). When OC14 cells were depleted of total glutathione to absolute levels less than HA1 cells and exposed to NO, they demonstrated a significant reduction in clonogenic cell survival. Comparison of clonogenic survival between glutathionedepleted HA1 cells and OC14 cells plated at equal densities and exposed to equal doses of NO demonstrates that OC14 cells survive at a significantly greater extent (50\%) than do HA1 cells (8\%). Thus, OC14 cells remain significantly more resistant to reactive nitrogen species injury, relative to HA1 cells, despite glutathione depletion to levels below the limits of assay detection $(0.2 \mu \mathrm{g} / \mathrm{mg}$ protein). Experiments designed to determine the effects of exposing glutathione-depleted HA1

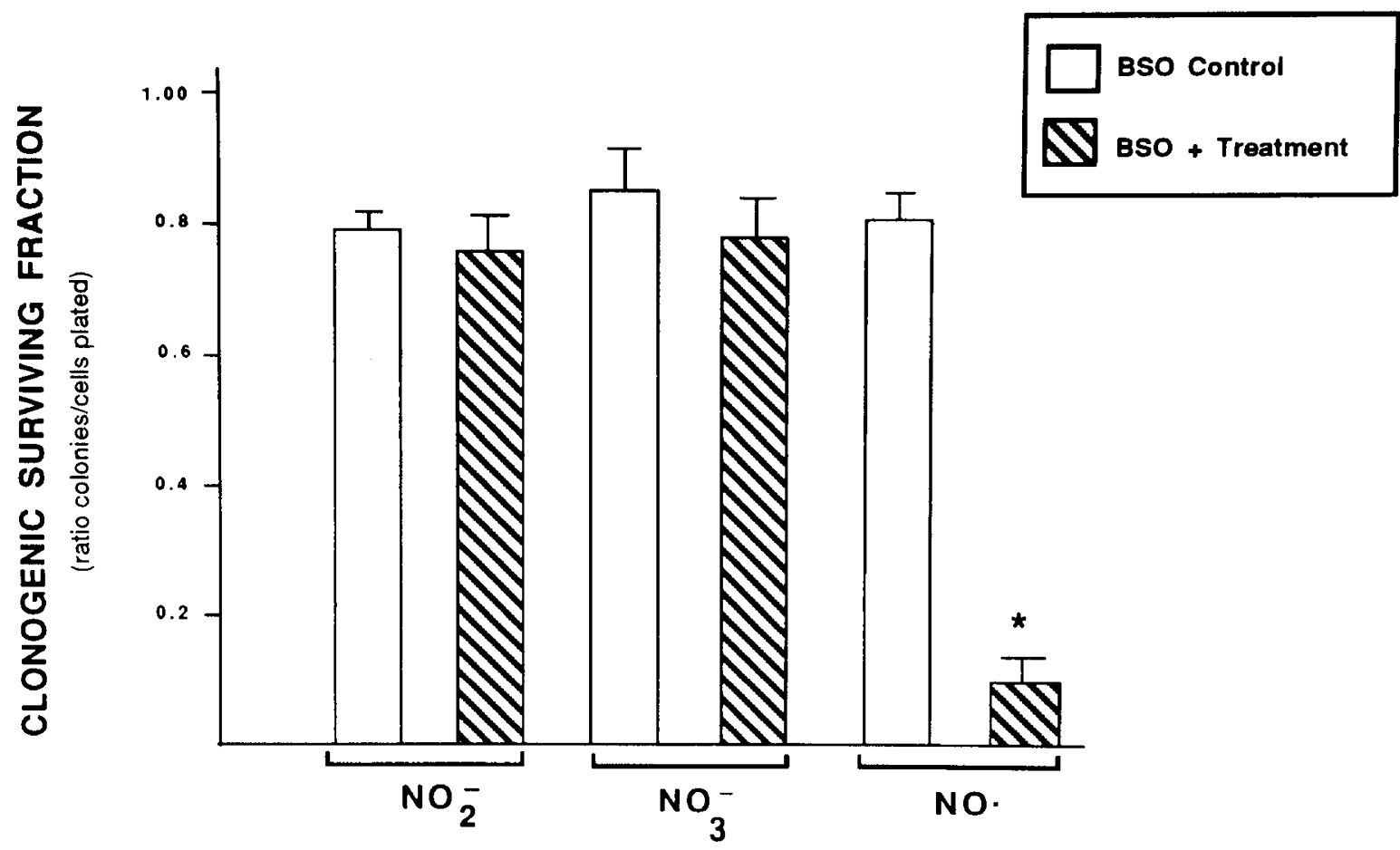

Figure 6. Effects of nitrites $\left(\mathrm{NO}_{2}{ }^{-}\right)$and nitrates $\left(\mathrm{NO}_{3}{ }^{-}\right)$on clonogenic survival of $\mathrm{HA1}$ cells with total glutathione depletion. Effects of 60 min of exposure to $5 \mathrm{mM}$ nitrite $\left(\mathrm{NO}_{2}{ }^{-}\right), 5 \mathrm{mM}$ nitrate $\left(\mathrm{NO}_{3}{ }^{-}\right)$, and $1.7 \mathrm{mM}$ NO on the clonogenic survival of HA1 fibroblasts with BSO pretreatment. Data expressed as mean $\pm \mathrm{SD}$. An asterisk represents $p<0.05$ vs respective control. 


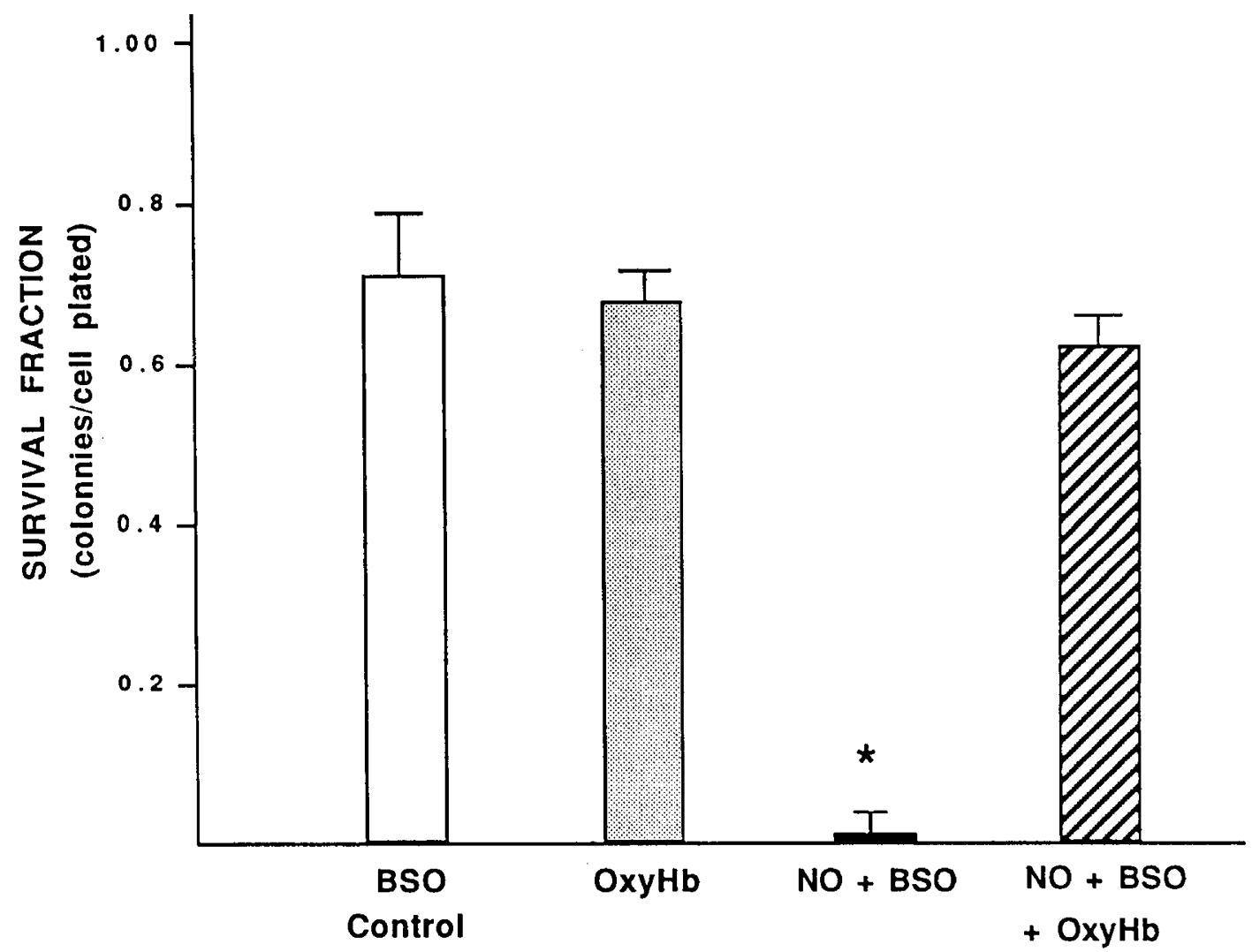

Figure 7. Oxyhemoglobin protection of total glutathione-depleted HA1 cells from NO-mediated injury. Effects of $100 \mu \mathrm{M}$ oxyhemoglobin $(O x y H b)$ on the clonogenic survival of HA1 fibroblasts with BSO pretreatment after $60 \mathrm{~min}$ of exposure to $1.7 \mathrm{mM} \mathrm{NO}$-containing medium solution. Data expressed as mean $\pm \mathrm{SD}$. Asterisk represents $p<0.05$ vs respective control.

cells to nitrite or nitrate, potential toxic metabolites from the reaction of NO and oxygen, demonstrated no effect on cell clonogenic survival. However, the ability of oxyhemoglobin to protect HA1 cells from saturated NO-containing medium demonstrates that the reactive nitrogen species involved in producing the cytotoxic response in this cell model originate from NO.

NO has been reported to contribute to cytotoxic and cytoprotective reactions in a number of in vitro cell experiments (11-18). Controversy about the role of endogenous or exogenous NO exists in a number of scenarios including ischemiareperfusion injury (18), neurotoxicity (15-17), and leukocytemediated and autoimmune diseases $(3,27,28)$. Two critical characteristics of NO that may account for the apparent conflicting reports in the literature include the observation that NO is known to exist in a number of oxidation states (29) and that $\mathrm{NO}$ is an extremely reactive free radical with a $t_{1 / 2}$ of $3-5 \mathrm{~s}$ in physiologic conditions (4). NO has been hypothesized to exist in the reduced state, $\mathrm{NO}$; a state observed when $\mathrm{NO}$ is in the gaseous state, when $\mathrm{NO}$ is physiologically secreted, or when NO is released by pharmacologic agents such as 3-morpholinosydnonimine (SIN-1) (29). As a reduced free radical, NO has been shown to avidly react with oxygen and superoxide anion to yield potentially cytotoxic agents such as $\mathrm{NO}_{2} \cdot$ and peroxynitrite $\left(\mathrm{OONO}^{-}\right)(29-31)$. The reaction of $\mathrm{NO}$ and oxygen is complete upon formation of nitrite and nitrate. Although nitrite and nitrate are not toxic in our in vitro model, other reactive nitrogen species may be involved. Reduced NO is also capable of avidly binding with sulfhydryl groups, such as those found in thiols, and with ferrous heme molecules, such as found in guanylate cyclase and $\mathrm{Hb}(30,48,49)$. Other investigators have postulated that some of the physiologic effects of NO are mediated via formation of stable nitrosothiol compounds that results in a decreased pool of highly reactive reduced NO (32).

Formation of stable nitrosothiol-intermediate compounds is hypothesized as an explanation for our experimental results in which cytotoxic responses followed exposure to bolus concentrations of reduced aqueous NO. We speculate that intracellular glutathione pools act to scavenge reactive species derived from NO directly or act as cofactors in reactions that detoxify oxidized cell components, such as lipids, after damaging reactions initiated by NO-derived species. These types of glutathione-mediated reactions could effectively limit the cytotoxicity seen in HA1 and OC14 cells after NO exposure. The formation of nitrosothiols or other glutathione conjugates could also explain the loss of total glutathione content seen in HA1 and OC14 cells after NO exposure, because these compounds cannot be measured by our assay. Experimental support for the hypothesis that nitrosothiol formation results from reactions between NO and glutathione in aqueous medium and that subsequent glutathione depletion results in enhanced toxicity to NO or NO-donating pharmacologic agents has been reported by others (49). Thus, glutathione appears to protect cells from toxicity associated with exposure to the products of the $\mathrm{NO}$ / oxygen reaction. Exposure of increasing numbers of total 
glutathione-depleted HA1 cells to saturated NO-containing medium resulted in increased clonogenic survival. This result (Fig. $2 B$ ) can be explained by assuming that the total cell population has reduced toxicity due to the collective protection provided by some non-glutathione-dependent mechanism(s). Specifically, metabolism of NO to other nontoxic products or a decrease in the dose of NO per cell may explain the protection afforded by increasing cell density.

The participation of other, non-glutathione-dependent, protective pathways is also demonstrated by the observation that glutathione-depleted OC14 cells are less sensitive to the toxicity of NO-containing medium than are similarly glutathionedepleted HA1 cells despite both cell lines having nondetectable levels of total glutathione. OC14 cells are known to have elevated activities of several antioxidant systems when compared with HA1 cells including total glutathione (2-3 times greater), catalase (20 times greater), $\mathrm{CuZn}$ superoxide dismutase (1.8 times greater), glutathione peroxidase (2 times greater), and glutathione transferase (2 times greater) $(20,26)$. It is possible that the elevations of these other antioxidant enzymes or the activity of other intracellular protective mechanisms associated with resistance to oxidative stress (i.e. repair of oxidative damage) may contribute to the decreased sensitivity of OC14 cells to NO exposure in the absence of glutathione.

NO-mediated toxicity occurs very rapidly in our cell model. Other investigators have reported rapid NO inhibitory effects on the mitogenic capabilities of other cell lines in vitro (33, 34). Additional reports have suggested the NO, or NO-derived, species are capable of causing oxidative injury $(35-45,49)$. Aqueous NO in the presence of oxygen has been shown to generate a species that is a potent oxidant capable of reacting with glutathione $(19,49)$. Our experimental results, which demonstrated a role for glutathione in protection from NOmediated injury and that cellular resistance to oxidative stress also confers resistance to aqueous NO, indirectly support a causal role for NO-mediated oxidative injury in this model of NO toxicity. However, caution is warranted in extrapolating the results of these experiments to the clinical situation due to the inherent toxicity differences existing between NO bolus dosing in in vitro studies and the continuous steady state exposure to NO that is likely to occur in vivo. Additional verification studies are needed.

In conclusion, this cell model demonstrates that 1 ) $\mathrm{NO}$, or some other reactive nitrogen species derived from NO (other than nitrites or nitrates), is responsible for decreases in clonogenic cell survival and trypan blue dye exclusion capabilities; 2) biochemical pathways associated with cellular resistance to oxidative stress also confer resistance to NO-mediated cytotoxicity; and 3) the cellular content of total glutathione determines a significant portion of cell sensitivity to NO-mediated cytotoxicity. Future investigation will focus on specifically identifying the injurious reactive nitrogen species, the critical biomolecules damaged during production of this injury, and the involvement of other antioxidant systems in protection against NO-mediated cytotoxicity. Finally, although the bolus doses of NO used in our in vitro experiments are higher than could be achieved using $<100 \mathrm{ppm}$ inhaled NO in vivo, we urge continued evaluation of inhaled NO therapy, particularly in neonates who have demonstrated an enhanced susceptibility to oxidative injury. Special emphasis should be placed on establishing NO dose-response curves and toxicity-exposure outcomes.

Acknowledgment. The authors thank Donna T. Adams for technical advice and assistance.

\section{REFERENCES}

1. Palmer RMJ, Ferrige AC, Moncada S 1987 Nitric oxide release accounts for the biological activity of endothelium-derived relaxing factor. Nature 327:524-526

2. Ignarro LJ, Byrns RE, Buga GM, Wood KS 1987 Endothelium-derived relaxing factor from pulmonary artery and vein possesses pharmacologic and chemical properties identical to those of nitric oxide radical. Circ Res 61:866-879

3. Moncada S, Palmer RMJ 1991 Biosynthesis and actions of nitric oxide. Semin Perinatol 15:16-19

4. Ignarro LJ 1991 Physiological significance for endogenous nitric oxide. Semin Perinatol 15:20-26

5. Roberts JD, Polaner DM, Lang P, Zapol WM 1992 Inhaled nitric oxide in persistent pulmonary hypertension of the newborn. Lancet 1:818-819

6. Kinsella JP, Neish SR, Shaffer E, Abman SH 1992 Low-dose inhalation nitric oxide in persistent pulmonary hypertension of the newborn. Lancet 1:819-820

7. Rossaint R, Falke KJ, Lopez F, Slama K, Pison U, Zapol WM 1993 Inhaled nitric oxide for the adult respiratory distress syndrome. N Engl J Med 328:399-405

8. Nakajima T, Oda H, Kusumoto S, Nogami H 1980 Biological effects of nitrogen dioxide and nitrogen oxide. In: Lee SH (ed) Nitrogen Oxides and Their Effects on Health. Ann Arbor Science, Ann Arbor, MI, pp 121-142

9. Clutton-Brack J 1967 Two cases of poisoning by contamination of nitrous oxide with higher oxides of nitrogen during anaesthesia. Br J Anaesth 39:388-392

10. Stavent DM, Lehnert BE 1990 Nitric oxide and nitrogen dioxide as inducers of acute pulmonary injury when inhaled at relatively high concentrations for brief periods. Inhal Toxicol 2:53-67

11. Johnson G, Tsao PS, Lefer AM 1991 Cardioprotective effects of authentic nitric oxide in myocardial ischemia with perfusion. Crit Care Med 19:244-252

12. Gambassi F, Pistelli A, Di Bello MG, Lupini M, Mannaioni PF, Masini E 1992 Ischemia-reperfusion injury and histamine release in isolated perfused guinea pig heart: effect of nitric oxide generators. Pharmacol Res 25:11-12

13. Linz W, Wiemer G, Scholken BA 1992 ACE-inhibition induces NO-formation in cultured bovine endothelial cells and protects isolated ischemic rat hearts. J Mol Cell Cardiol 24:909-919

14. Wink DA, Hanbauer I, Krishna MC, DeGraff W, Gamson J, Mitchell JB 1993 Nitric oxide protects against cellular damage and cytotoxicity from reactive oxygen species. Proc Natl Acad Sci USA 90:9813-9817

15. Dawson VL, Dawson TM, London ED, Bredt DS, Snyder SH 1991 Nitric oxide mediates neurotoxicity in primary cortical cultures. Proc Natl Acad Sci USA 88:6368-6371

16. Dawson VL, Dawson TM, Bartley DA, UhI GR, Snyder SH 1993 Mechanisms of nitric oxide-mediated neurotoxicity in primary brain cultures. J Neurosci 13:26512661

17. Cazevieille C, Muller A, Megnier F, Bonne C 1993 Superoxide and nitric oxide cooperate in hypoxia/reoxygenation-induced neuron injury. Free Rad Biol Med 14:389-395

18. Beckman JS, Beckman TW, Chen J, Marshall PA, Freeman BA 1990 Apparent hydroxyl radical production by peroxinitrite: implications for endothelial injury from nitric oxide and superoxide. Proc Natl Acad Sci USA 87:1620-1624

19. Wink DA, Darbyshire JF, Nims RW, Saavedra JE, Ford PC 1993 Reaction of the bioregulatory agent nitric oxide in oxygenated aqueous media: determination of the kinetics for oxidation and nitrosation by intermediates generated in the $\mathrm{NO} / \mathrm{O}_{2}$ reaction. Chem Res Toxicol 6:23-27

20. Spitz DR, Elwell JH, Sun Y, Oberley LW, Oberley TD, Sullivan SJ, Roberts RJ 1990 Oxygen toxicity in control and $\mathrm{H}_{2} \mathrm{O}_{2}$-resistant Chinese hamster fibroblast cell lines. Arch Biochem Biophys 279:249-260

21. Sullivan SJ, Oberley TD, Roberts RJ, Spitz DR 1992 A stable $\mathrm{O}_{2}$-resistant cell line: role of lipid peroxidation byproducts in $\mathrm{O}_{2}$-mediated injury. Am J Physiol 262:L748L756

22. Boje KM, Fung M 1990 Endothelial nitric oxide generating enzymes in the bovine aorta: subcellular location and metabolic characterization. J Pharm Exp Ther 253:20-26

23. Menon NK, Wolf A, Zehetgruber M, Bing RJ 1989 An improved chemiluminescence assay suggests non nitric oxide-mediated action of lysophosphatidylcholine and acetylcholine. Proc Soc Exp Biol Med 191:316-319

24. Green LC, Wagner DA, Glogowski J, Skipper PL, Wishnok JS, Tannenbaum SR 1982 Analysis of nitrate, nitrite and $(15 \mathrm{~N})$ nitrate in biological fluids. Anal Biochem 126:131-138

25. Feelisch M, Noack EA 1987 Correlation between nitric oxide formation during degradation of organic nitrates and activation of guanylate cyclase. Eur J Pharmacol 139:19-30

26. Spitz DR, Malcolm RR, Roberts RJ 1990 Cytotoxicity and metabolism of 4-hydroxy2-nonenal and 2-nonenal in $\mathrm{H}_{2} \mathrm{O}_{2}$-resistant cell lines. Do aldehydic by-products of lipid peroxidation contribute to oxidative stress? Biochem J 267:453-459 
27. Stuehr DJ, Nathan CF 1989 Nitric oxide: A macrophage product responsible for cytostasis and respiratory inhibition in tumor target cells. J Exp Med 169:1543-1555

28. Fehsel K, Jalowy A, Qi S, Burkart V, Hartmann B, Kolb H 1993 Islet cell DNA is a target of inflammatory attack by nitric oxide. Diabetes 42:496-500

29. Lipton SA, Choi Y-B, Pan Z-H, Lei, SZ, Chen H-SV, Sucher NJ, Loscalso J, Singel DJ, Stamler JS 1993 A redox-based mechanism for the neuroprotective and neurodestructive effects of nitric oxide and related nitroso-compounds. Nature 364:626-632

30. Grisham, MB 1992 Reactive Nitrogen Metabolism. In: Grisham MB (ed) Reactive Metabolites of Oxygen and Nitrogen in Biology and Medicine. RG Landis, Co., pp $70-100$

31. Saran M, Michel C, Bors W 1990 Reaction of $\mathrm{NO}$ with $\mathrm{O}_{2}-$ : implications for the action of endothelium-derived relaxing factor (EDRF). Free Rad Res Commun 10:221-226

32. Chong S, Fung HL 1991 Biochemical and pharmacological interactions between nitroglycerine and thiols. Effects of thiol structure on nitric oxide generation and tolerance reversal. Biochem Pharmacol 42:1433-1439

33. Garg UC, Hassid A 1989 Nitric oxide-generating vasodilators and 8-bromo-cyclic guanosine monophosphate inhibit mitogenesis and proliferation of cultured rat vascular smooth muscle cells. J Clin Invest 83:1774-1777

34. Garg UC, Hassid A 1989 Inhibition of rat mesangial cell mitogenesis by nitric oxide-generating vasodilators. Am J Physiol 257:F60-F66

35. Patel JM, Block ER 1986 Nitrogen dioxide-induced changes in cell membrane fluidity and function. Am Rev Respir Dis 134:1196-1202

36. Pryor WA, Lightsey JW 1981 Reports: Mechanism of nitrogen dioxide reactions: initiation of lipid peroxidation and the production of nitrous acid. Science 214:435437

37. Wink DA, Kasprzak KS, Marago CM, Elespuru RK, Misra M, Danams TM, Cebula TA, Koch WH, Andrews AW, Allen JS, Keefer LK 1991 DNA deaminating ability and genotoxicity of nitric oxide and its progenitors. Science 254:1001-1003

38. Nguyen T, Brunson D, Crespi CL, Penman BW, Wishnole JS, Tannenbaum SR 1992 DNA damage and mutation in human cells expose to nitric oxide in vitro. Proc Natl Acad Sci USA 89:3030-3034
39. Isomura K, Chikahira M, Teranishi K, Hamada K 1984 Induction of mutations and chromosome aberrations in lung cells following in vivo exposure of rats to nitrogen oxides. Mutation Res 136:119-125

40. Bittrich H, Matzig AK, Kraker I, Appel KE $1993 \mathrm{NO}_{2}$-induced DNA single strand breaks are inhibited by antioxidant vitamins in V79 cells. Chem-Biol Interactions 86:199-211

41. Gorsdorf S, Appel KE, Engelholm C, Obe G 1990 Nitrogen dioxide induces DNA single-strand breaks in cultured Chinese hamster cells. Carcinogenesis 11:37-41

42. Kwon, NS, Stuehr, DJ, Nathan, DF 1991 Inhibition of tumor cells ribo-nucleotide reductase by macrophage-derived nitric oxide. J Exp Med 174:761-767

43. Lepoivre M, Fiesch F, Coves J, Thelande, L, Fontecave M 1991 Inactivation of ribonucleotide reductase by nitric oxide. Biochem Biophys Res Commun 179:442448

44. Curran RD, Ferrari FK, Kispert PH, Stadler J, Stuehr DJ, Simmons, RL, Billiar TR 1991 Nitric oxide and nitric oxide-generating compounds inhibit hepatocyte protein syntheses. FASEB J 5:2085-2092

45. Arroyo PL, Hatch-Pigott V, Mower HF, Cooney RV 1992 Mutagenicity of nitric oxide and its inhibition by antioxidants. Mutat Res 281:193-202

46. Biaglow JE, Varnes ME 1983 The role of thiols in cellular response to radiation and drugs. Radiat Res 95:437-455

47. Mitchell JB, Russo A 1983 Thiols, thiol depletion, and thermosensitivity. Radiat Res 95:471-485

48. Laval F, Wink DA 1994 Inhibition by nitric oxide of the repair protein, $\mathrm{O}^{6}$ methylguanine-DNA-methyltransferase. Carcinogenesis 15:443-447

49. Wink DA, Nims RW, Darbyshire JF, Christodoulou P, Hanbauer I, Cox GW, Laval F, Laval J, Cook JA, Krishna MC, DeGraff WG, Mitchell JB 1994 Reaction kinetics for nitrosation of cysteine and glutathione in aerobic nitric oxide solutions at neutral pH. Insights into the fate and physiological effects of intermediates generated in the $\mathrm{NO} / \mathrm{O}_{2}$ reaction. Chem Res Toxicol 7:519-525 